\title{
Implementasi Algoritma Sequential Searching Pada Sistem Pelayanan Puskesmas Menggunakan Bootstrap (Studi Kasus Puskesmas Kampung Bali Bengkulu)
}

\author{
Marissa Utami ${ }^{1}$,Yovi Apridiansyah ${ }^{2}$ \\ Program Studi Informatika, Fakultas Teknik, Universitas Muhammadiyah Bengkulu \\ Jl. Bali, Bengkulu 38119 \\ marissautami@umb.ac.id ${ }^{l,}$ yoviapridiansyah@umb.ac.id ${ }^{2}$
}

\begin{abstract}
Kampung Bali is a public health Agencies engaged in public health services. Kampung Bali clinics still doing service to patients by manual search data such as patient data, patient pengelolahan, the recording of the examination of the patients still using the form, the management report data checks and drug data still using manual bookkeeping. Patient data storage media using the media of paper resulting in a data search is done by searching the archives can be time-consuming and still done manually by means of merekap patient data via the archives that can be time-consuming additionally vulnerable with errors. To support system development method of service Puskemas author using the method waterfall on system development, implementation of algorithms for data search system on Sequiential Searchin patients, and use the display Boostrap.
\end{abstract}

\begin{abstract}
Abstrak- Puskesmas Kampung Bali merupakan suatu Instansi yang bergerak dibidang pelayanan kesehatan masyarakat. Puskesmas Kampung Bali masih melakukan pelayanan terhadap pasien dengan cara manual seperti pencarian data pasien, pengelolahan data pasien, pencatatan pemeriksaan pasien masih menggunakan formulir, pengelolaan laporan data pemeriksaan dan data obat yang masih menggunakan pembukuan manual. Media penyimpanan data pasien menggunakan media kertas sehingga mengakibatkan pencarian data dilakukan dengan cara menelusuri arsip-arsip yang dapat menyita waktu dan masih dikerjakan secara manual dengan cara merekap data-data pasien melaui arsip-arsip yang dapat menyita waktu selain itu rentan dengan kesalahan. Untuk mendukung metode pengembangan sistem pelayanan Puskemas penulis menggunakan metode waterfall pada pengembangan sistem, implementasi Algoritma Sequiential Searching pada sistem pencarian data pasien, dan menggunakan tampilan Boostrap. Keyword: Sistem Pelayanan, Puskemas, Sequential, Boostrap
\end{abstract}

\section{PENDAHULUAN}

Pemanfaatan teknologi pada bidang kesehatan serta tingginya tuntutan masyarakat terhadap pelayanan kesehatan yang lebih berkualitas menutut dikembangkannya sistem pelayanan Puksesmas terpadu guna untuk mendukung kinerja. Pusat Kesehatan Masyarakat merupakan salah satu sarana pelayanan kesehatan masyarakat yang amat penting di Indonesia yang memberikan pelayanan secara menyeluruh, terpadu dan berkesinambungan kepada masyarakat dalam suatu wilayah kerja tertentu dalam bentuk usahausaha kesehatan pokok dan langsung berada dalam pengawasan administratif maupun teknis dari Dinas Kabupaten. [1]

Puskesmas Kampung Bali Kota Bengkulu masih melakukan pelayanan terhadap pasien dengan cara manual seperti pencarian data pasien, pengelolahan data pasien, pencatatan pemeriksaan pasien masih menggunakan formulir, pengelolaan laporan, data pemeriksaan dan data obat yang masih menggunakan pembukuan manual.
Sequential Searching merupakan teknik pencarian data dengan cara masukan berupa sebuah kata kunci lalu mulai dari awal (atau dari akhir) cek seluruh record dalam array atau list, dengan membaca satu persatu berdasarkan key yang dicari, apabila sampai akhir pengulangan data tidak ada yang sama maka data tidak ditemukan. Kelebihan dari proses pencarian sequential searching, jika data yang dicari terletak didepan, maka data akan ditemukan dengan cepat dan model pencarian yang paling sederhana yang dilakukan terhadap suatu kumpulan data.

\section{A. Sistem}

Dalam mendefinisikan sistem dapat menggunakan 2 (dua) pendekatan. Menurut Taufiq, sistem ditafsirkan sebagai kesatuan elemen yang memiliki keterkaitan. Beberapa elemen dapat digabung menjadi suatu unit, kelompok atau komponen sistem dengan fungsi tertentu. Komponen sistem ini bisa dilihat, dianggap, atau memang dirancang untuk berfungsi mandiri sebagai modul sistem. [2] 
Menurut Jogiyanto, sistem dapat didefinisikan dengan sekumpulan dari elemen-elemen yang berinteraksi untuk mencapai suatu tujuan tertentu. Dengan pendekatan prosedur, sistem dapat didefinisikan sebagai kumpulan dari prosedur-prosedur yang mempunyai tujuan tertentu. Contoh sistem yang didefinisikan dengan pendekatan prosedur ini adalah sistem akuntansi. Sistem ini didefinisikan sebagai kumpulan dari prosedur-prosedur penerimaan kas, pengeluaran kas, penjualan, pembelian dan buku besar. Sedangkan dengan pendekatan komponen, sistem dapat didefinisikan sebagai kumpulan dari komponen yang saling berhubungan satu dengan yang lainnya membentuk satu kesatuan untuk mencapai tujuan tertentu.[3]

\section{B. Pelayanan Kesehatan}

Pelayanan kesehataan merupakan sebuah konsep yang digunakan dalam memberikan layanan kesehatan kepada masyarakat. Menurut Sianipar, pelayanan merupakan meladeni atau membantu mengurus keperluan atau kebutuhan sesorang sejak diajukan permintaan sampai penyampaian atau penyerahannya. Menurut Notoadmodjo, pelayanan kesehatan merupakan setiap kegiatan atau serangkaian yang dilakukan secara terpadu, terintegrasi dan berkesinambungan untuk memelihara dan meningkatkan derajat kesehatan, pengobatan penyakit, dan pemulihan kesehatan oleh pemerintah atau masyarakat".[4]

\section{Bootstrap}

Menurut Alatas, Bootstrap merupakan library yang biasa digunakan untuk membuat aplikasi web ataupun situs web responsive secara cepat, mudah dan gratis. TwitterBootstrap ini terdiri dari CSS (Cascading Style Sheet )dan HTML untuk menghasilkan grid, layout, typography, table, form, navigation dan lain-lain. Selain itu, di dalam Bootstrap juga sudah terdapat jqueryplugins untuk menghasilkan komponen user interface yang cantik seperti transitions, modal, dropdown, scrollspy, tooltip, tab, alert dan lain-lain. [5]

\section{Sequential Searching}

Pencarian (searching) merupakan proses menemukan nilai (data) tertentu didalam sekumpulan data yang bertipe sama (baik bertipe dasar maupun bertipe bentukan). Sequential Searching merupakan teknik pencarian data secara urut dari depan ke belakang atau dari awal sampai akhir berdasarkan key yang dicari dalam array 1 dimensi. Data yang akan dicari nanti akan ditelusuri dalam semua elemen-elemen array dari awal sampai akhir, dan data yang dicari tersebut tidak perlu diurutkan terlebih dahulu apabila sampai akhir pengulangan tidak ada data yang sama, berarti data yang dimaksud tidak ada. Terdapat $\mathrm{L}$ yang merupakan larik yang berisi $\mathrm{n}$ buah data $(\mathrm{L}[0]$, $\mathrm{L}[1], \ldots, \mathrm{L}[\mathrm{n}-1]$ dan $\mathrm{k}$ adalah data yang hendak dicari. Pencarian dilakukan untuk menemukan L[i]=k Dengan i adalah bilangan index terkecil yang memenuhi kondisi $0 \leq \mathrm{k} \leq \mathrm{n}-1$. Tentukan saja ada kemungkinan bahwa data yang dicari tidak ditemukan. [6]

Berikut cara kerja dari Metode Sequential search:

1. $\mathrm{i} \leftarrow 0$

2. ditemukan $\leftarrow$ false

3. Selama (tidak ditemukan) dan $(\mathrm{i}<=\mathrm{N})$ kerjakan baris 4

4. Jika $(\operatorname{Data}[\mathrm{i}]=\mathrm{x})$ maka ditemukan $\leftarrow$ true, jika tidak $\mathrm{i} \leftarrow \mathrm{i}+1$

5. Jika (ditemukan) maka i adalah indeks dari data yang dicari,jika data tidak ditemukan berarti data tidak ada

\section{METODE PENELITIAN}

Dalam penelitian ini model pengembangan sistem yang digunakan yaitu model Incremental. Incremental model adalah model pengembangan sistem pada rekayasa perangkat lunak berdasarkan perangkat lunak persyaratan yang dipecah menjadi beberapa fungsi atau bagian sehingga model pengembangannya secara bertahap.

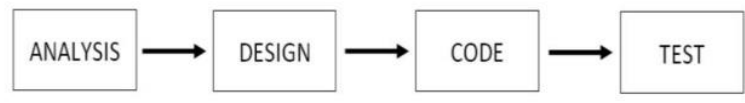

Gbr. 1 Metode Incemental

\section{A. Analisis}

Analisis data diartikan sebagai upaya mengolah data menjadi informasi, sehingga karakteristik atau sifat-sifat data tersebut dapat dengan mudah dipahami dan bermanfaat untuk menjawab masalah-masalah yang berkaitan dengan kegiatan penelitian.

\section{B. Design}

Dalam tahapan design ini Menghasilkan rancangan yang memenuhi kebutuhan yang ditentukan selama tahapan analisis. Hasil akhirnya berupa spesifikasi rancangan yang sangat rinci sehingga mudah diwujudkan pada saat pemrograman. 


\section{DFD (Data Flow Diagram)}

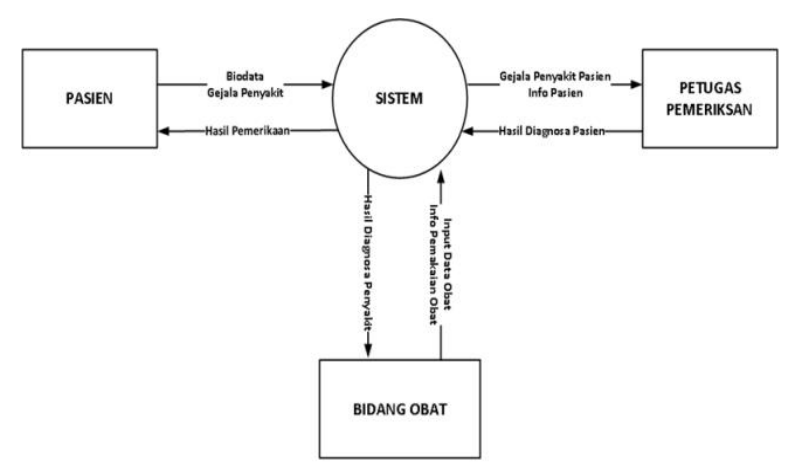

Gbr. 2 DFD Sistem Puskemas

\section{ERD (Entity RelationshipDiagram)}

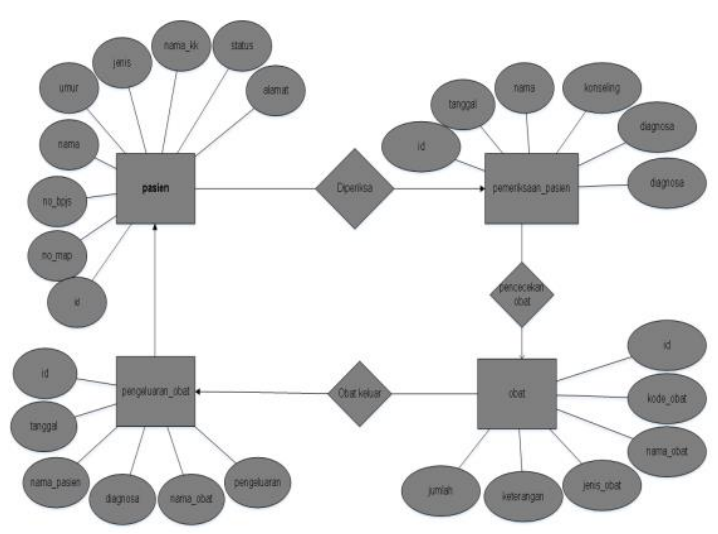

Gbr. 3 ERD Sistem Puskemas

\section{Code}

Pengkodean yang mengimplementasikan hasil desain kedalam kode atau bahasa yang dimengerti oleh mesin komputer dengan menggunakan bahasa pemrograman Web.

Pada tahap pengkodean system penulisan kode program merupakan tahap penerjemahan desain sistem yang telah dibuat ke dalam bentuk perintah-perintah yang dimengerti komputer dengan mempergunakan bahasa pemrograman. Sistem ini bahasa pemrograman yang dipakai adalah PHP, database MySQL dan Implementasi Bootstrap.

\section{Test}

Dalam tahapan test merupakan tahap pengujian dalam model pengembangan sistem yang dibuat dengan melakukan secara berurutan pada setiap bagian-bagian agar menggurangi kendala dalam proses pemakaian dari pengguna. Pada tahapan sesudah software dibuat perlu dilakukan pengujian perangkat lunak. Setelah program dan database selesai penulis memilih metode pengujian sistem menggunakan black box testing dan white box testing.

\section{HASIL DAN PEMBAHASAN}

Pada tahap implementasi sistem, rancangan dan desain sistem diimplementasikan dengan bahasa pemrograman menggunakan bahasa pemrograman PHP My SQL dengan hasil dari data-data yang telah didapatkan.

\section{A. Tampilan Database}

Database Puskemas terdiri dari 4 tabel yaitu tabel admin, tabel obat, tabel pasien, tabel pemeriksaan pasien.

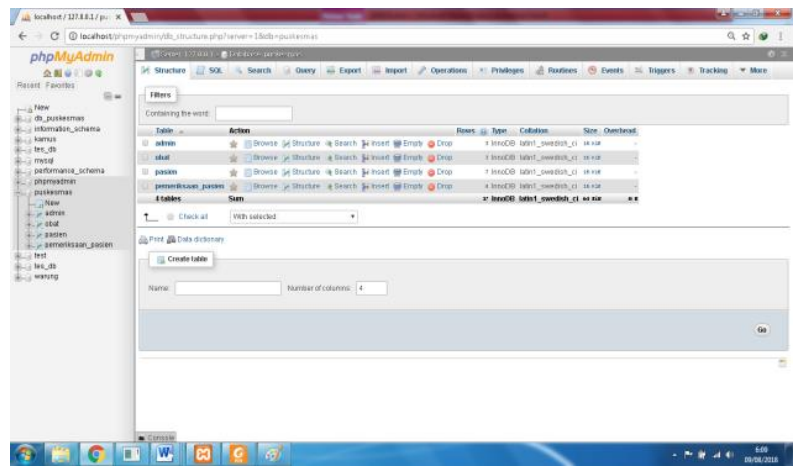

Gbr. 4 Tampilan Database Puskemas

\section{B. Menu Login}

Gbr. 5 Tampilan Menu Login

Tampilan menu login ini menampilkan halaman awal program yang digunakan untuk mengakses sistem puskemas. Dalam pengkodean login digunakan enkripsi menggunakan Message Digest 5 (MD5) karena fungsi dari MD5 merupakan pengkodean yang cocok untuk program PHP MYSQL karena dianggap strong enkripsi yang dihasilkan.[7] 
C. Menu Utama

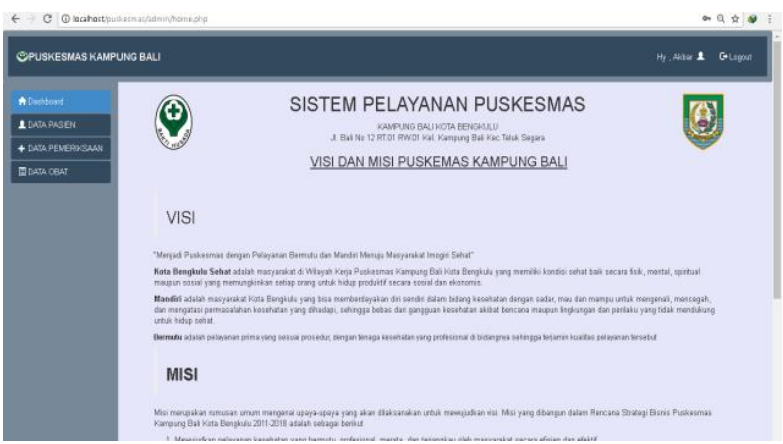

Gbr. 6 Tampilan Menu Utama

Menu utama berisi tampilan visi dan misi puskemas Kampung Bali Kota Bengkulu terdapat sub menu data pasien, data pemeriksaan, data obat, ganti password dan keluar.

\section{Menu Data Pasien}

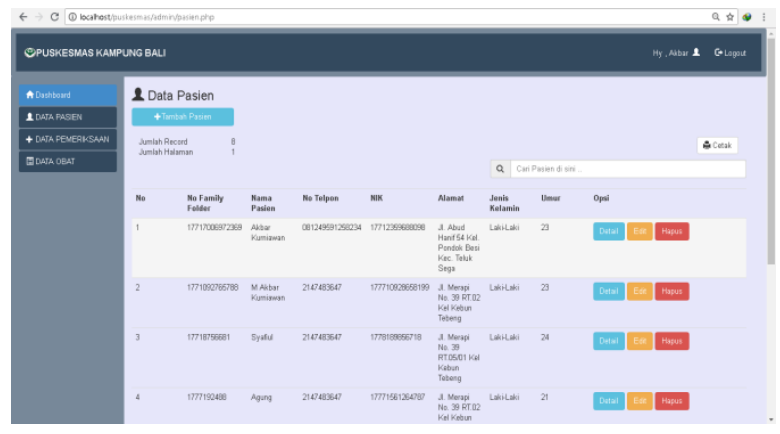

Gbr. 7 Menu Data Pasien

Tampilan Menu Data Pasien befungsi sebagai menampilkan data pasien yang sudah terdaftar, edit, dan hapus, Input data pasien yang baru, mencari data pasien dan cetak data.

\section{E. Menu Data Pemeriksaan}

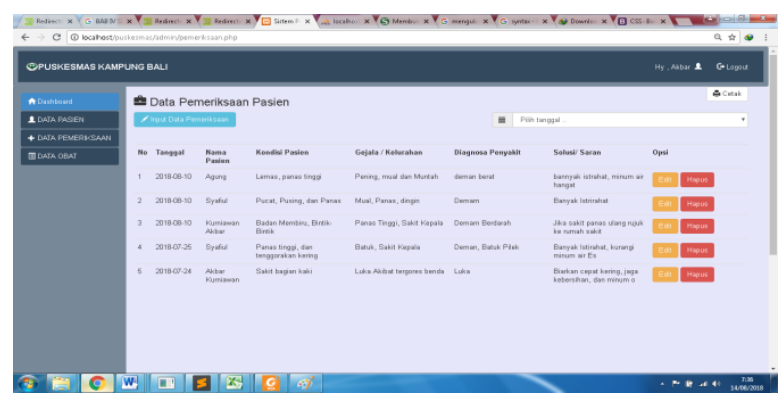

Gbr. 8 Tampilan Menu Data Pemeriksaan

Tempilan Menu Data Pemeriksaan Pasien, admin dapat memasukkan data hasil pemeriksaan dokter dengan langkah-langkah klik input data pemeriksaan pasien, isi semua formulir pada kemudian klik link tambah diagnosa hasil pemeriksaan.

\section{F. Menu Data Obat}

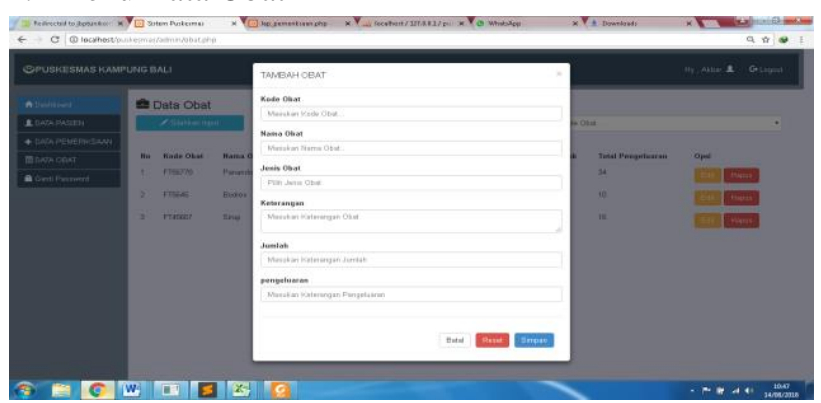

Gbr. 9 Tampilan Menu Data Obat

Pada Menu Data Obat berfungsi untuk mengolah penyimpanan, penambahan, pengeditan, hapus daftar tabel data obat.

\section{G. Menu Pemberian Obat}

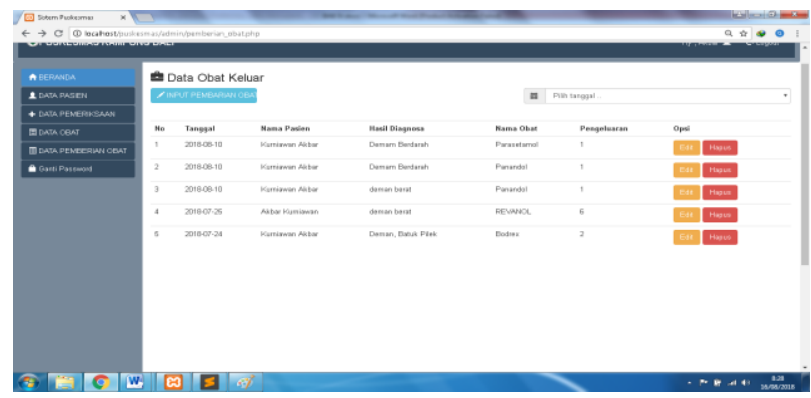

Gbr. 10 Tempilan Menu Pemberian Obat

Pada Tampulan Menu Pemberian Obat berfungsi untuk mengelolah data obat yang keluar/diberikan kepada pasien.

\section{Pengujian Sistem}

Pengujian yang dilakukan yaitu pengujian white box, pengujian black box. Pengujian white-box digunakan untuk meyakinkan semua perintah dan kondisi dieksekusi secara minimal. Pengujian Black Box Digunakan untuk menguji fungsi-fungsi khusus dari perangkat lunak yang dirancang. 
A. Pengujian White Box

Pengujian white-box digunakan untuk meyakinkan semua perintah dan kondisi pada aplikasi dieksekusi secara minimal. Pengujian white-box digunakan untuk menggambarkan alur dari algoritma.

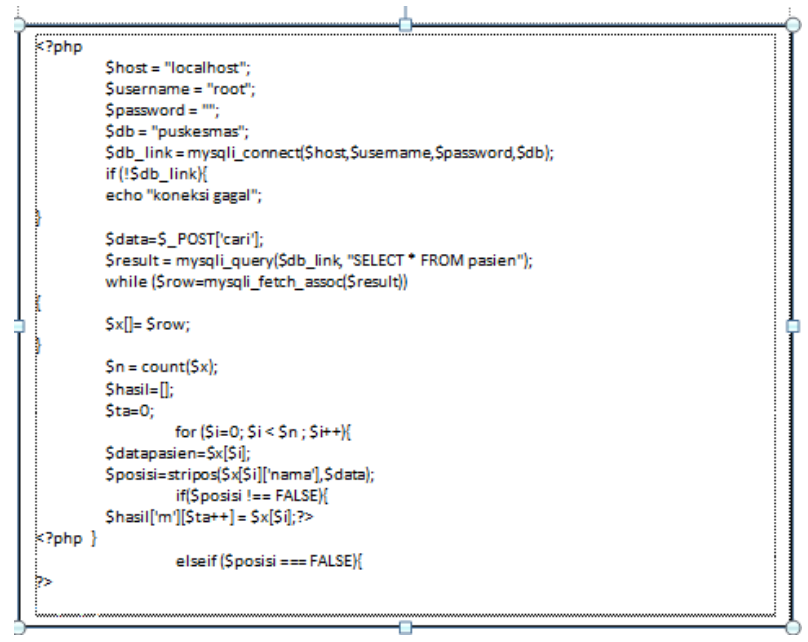

Gbr. 11 Tampilan Algoritma Sequential

TABEL I

KASUS DAN PENGUJIAN WHITE-BOX

\begin{tabular}{|c|l|l|l|}
\hline $\begin{array}{c}\text { Hal } \\
\text { yang } \\
\text { di Uji }\end{array}$ & Skenario & \multicolumn{1}{|c|}{$\begin{array}{c}\text { Hasil yang } \\
\text { diharapan }\end{array}$} & $\begin{array}{c}\text { Hasil } \\
\text { Pengujian }\end{array}$ \\
\hline $\begin{array}{c}\text { Menca } \\
\text { ri } \\
\text { nama } \\
\text { pasien }\end{array}$ & $\begin{array}{l}\text { Input } \\
\text { nama } \\
\text { pasien } \\
\text { (Data } \\
\text { Benar) }\end{array}$ & $\begin{array}{l}\text { Data pasien } \\
\text { akan ditampilan } \\
\text { sesuai nomor } \\
\text { urut }\end{array}$ & $\begin{array}{l}{[\sqrt{ } \text { Diterima }} \\
{[\text { Ditolak }}\end{array}$ \\
\cline { 2 - 4 } & $\begin{array}{l}\text { Input } \\
\text { nama } \\
\text { pasien } \\
\text { Data } \\
\text { Salah })\end{array}$ & $\begin{array}{l}\text { Muncul } \\
\text { Peringatan } \\
\text { error Gagal }\end{array}$ & $\begin{array}{l}\text { [ ] Diterima } \\
{[\text { Ditolak }}\end{array}$ \\
\hline
\end{tabular}

B. Pengujian BlackBox

Pengujian Black Box digunakan untuk menguji fungsi-fungsi khusus dari perangkat lunak yang dirancang. Setelah melaksanakan pengujian maka dilanjutkan dengan kasus dan hasil pengujian.

TABEL II

PENGUJIAN BLACK BOX

\begin{tabular}{|c|c|c|c|}
\hline $\begin{array}{c}\text { Hal yang } \\
\text { di Uji }\end{array}$ & Skenario & $\begin{array}{l}\text { Hasil yang } \\
\text { diharapan }\end{array}$ & $\begin{array}{c}\text { Hasil } \\
\text { Pengujian }\end{array}$ \\
\hline \multirow[t]{2}{*}{ Login } & $\begin{array}{l}\text { Input Login } \\
\text { (Data Benar) }\end{array}$ & $\begin{array}{l}\text { User } \\
\text { masuk ke } \\
\text { sistem } \\
\text { (Menu } \\
\text { Utama }\end{array}$ & $\begin{array}{l}{[\sqrt{ }]} \\
\text { Diterima } \\
{[} \\
\text { Ditolak }\end{array}$ \\
\hline & Input Login & Muncu & {$[\sqrt{ }$} \\
\hline
\end{tabular}

\begin{tabular}{|c|c|c|c|}
\hline & ( Data Salah) & $\begin{array}{l}\text { Peringatan } \\
\text { error Gagal }\end{array}$ & $\begin{array}{l}\text { Diterima } \\
{[} \\
\text { Ditolak }\end{array}$ \\
\hline \multirow[t]{2}{*}{$\begin{array}{l}\text { Input } \\
\text { Data } \\
\text { Paisen }\end{array}$} & $\begin{array}{l}\text { Cari data, } \\
\text { Tambah } \\
\text { Data, } \\
\text { Edit,Hapus } \\
\text { Data, } \\
\text { Simpan }\end{array}$ & $\begin{array}{l}\text { Data } \\
\text { Tersimpan, } \\
\text { Data } \\
\text { Berhasil } \\
\text { diubah, } \\
\text { data } \\
\text { berhasil } \\
\text { dihapus, } \\
\text { data yang } \\
\text { sesuai } \\
\text { dengan } \\
\text { inputan }\end{array}$ & $\begin{array}{l}{[\sqrt{ }]} \\
\text { Diterima } \\
{[\text { ] Ditolak }}\end{array}$ \\
\hline & $\begin{array}{l}\text { Cari data, } \\
\text { Tambah } \\
\text { Data, Edit } \\
\text { Data, Hapus } \\
\text { Data, } \\
\text { Simpan Data } \\
\text { tidak sesuai } \\
\text { aturan }\end{array}$ & $\begin{array}{l}\text { Muncul } \\
\text { peringatan } \\
\text { error atau } \\
\text { data tidak } \\
\text { berhasil } \\
\text { simpan, } \\
\text { data yang } \\
\text { dicari tidak } \\
\text { ada }\end{array}$ & $\begin{array}{ll}{[\sqrt{ }} & ] \\
\text { Diterima } & \\
{[} & \\
\text { Ditolak } & \end{array}$ \\
\hline \multirow[t]{2}{*}{$\begin{array}{c}\text { Input } \\
\text { Data } \\
\text { Pemeriks } \\
\text { aan }\end{array}$} & $\begin{array}{l}\text { Cari data, } \\
\text { Tambah } \\
\text { Data, } \\
\text { Edit,Hapus } \\
\text { Data, } \\
\text { Simpan }\end{array}$ & $\begin{array}{l}\text { Data } \\
\text { Tersimpan, } \\
\text { Data } \\
\text { Berhasil } \\
\text { diubah, } \\
\text { data } \\
\text { berhasil } \\
\text { dihapus, } \\
\text { data yang } \\
\text { sesuai } \\
\text { dengan } \\
\text { inputan }\end{array}$ & $\begin{array}{l}{[\sqrt{ }]} \\
\text { Diterima } \\
{[} \\
\text { Ditolak }\end{array}$ \\
\hline & $\begin{array}{l}\text { Cari data, } \\
\text { Tambah } \\
\text { Data, Edit } \\
\text { Data, Hapus } \\
\text { Data, } \\
\text { Simpan Data } \\
\text { tidak sesuai } \\
\text { aturan }\end{array}$ & $\begin{array}{l}\text { Muncul } \\
\text { peringatan } \\
\text { error atau } \\
\text { data tidak } \\
\text { berhasil } \\
\text { simpan, } \\
\text { data yang } \\
\text { dicari tidak } \\
\text { ada }\end{array}$ & $\begin{array}{ll}{[\sqrt{ }} & ] \\
\text { Diterima } & \\
{[} & \\
\text { Ditolak } & \end{array}$ \\
\hline $\begin{array}{l}\text { Input } \\
\text { Data } \\
\text { Obat }\end{array}$ & $\begin{array}{l}\text { Cari data, } \\
\text { Tambah } \\
\text { Data, } \\
\text { Edit,Hapus } \\
\text { Data, } \\
\text { Simpan }\end{array}$ & $\begin{array}{l}\text { Data } \\
\text { Tersimpan, } \\
\text { Data } \\
\text { Berhasil } \\
\text { diubah, } \\
\text { data } \\
\text { berhasil } \\
\text { dihapus, } \\
\text { data yang } \\
\text { sesuai } \\
\text { dengan }\end{array}$ & 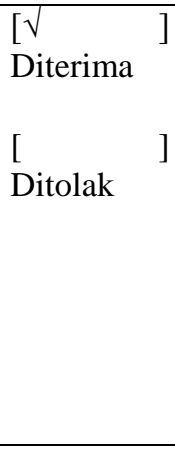 \\
\hline
\end{tabular}

85 | http://www.jurnal.umb.ac.id/index.php/JSAI 


\begin{tabular}{|c|c|c|c|c|}
\hline & & inputan & & \\
\hline & $\begin{array}{l}\text { Cari data, } \\
\text { Tambah } \\
\text { Data, Edit } \\
\text { Data, Hapus } \\
\text { Data, } \\
\text { Simpan Data } \\
\text { tidak sesuai } \\
\text { aturan }\end{array}$ & $\begin{array}{l}\text { Muncul } \\
\text { peringatan } \\
\text { error atau } \\
\text { data tidak } \\
\text { berhasil } \\
\text { simpan, } \\
\text { data yang } \\
\text { dicari tidak } \\
\text { ada }\end{array}$ & $\begin{array}{l}{[\sqrt{ }]} \\
\text { Diterima } \\
{[} \\
\text { Ditolak }\end{array}$ & ] \\
\hline \multirow[t]{2}{*}{ Laporan } & $\begin{array}{l}\text { Cetak } \\
\text { laporan data } \\
\text { sesuai } \\
\text { kategori dari } \\
\text { laporan }\end{array}$ & $\begin{array}{l}\text { Laporan } \\
\text { muncul } \\
\text { dan data } \\
\text { sesuai } \\
\text { dengan } \\
\text { kategori }\end{array}$ & $\begin{array}{l}\sqrt{ }] \\
\text { Diterima } \\
{[} \\
\text { Ditolak }\end{array}$ & ] \\
\hline & $\begin{array}{l}\text { Cetak } \\
\text { laporan data } \\
\text { sesuai } \\
\text { kategori }\end{array}$ & $\begin{array}{l}\text { Laporan } \\
\text { muncul } \\
\text { tanpa data }\end{array}$ & $\begin{array}{l}{[\sqrt{ }]} \\
\text { Diterima } \\
{[} \\
\text { Ditolak }\end{array}$ & 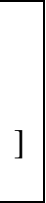 \\
\hline
\end{tabular}

\section{Kesimpulan}

Dari hasil pengujian sistem pelayanan puskemas kampung bali dengan menggunakan algoritma sequential Searching dan bootstrap berbasis php, dapat ditarik kesimpulan sebagai berikut:

1. Kesulitan dalam pencarian data pasien, dapat diatasi dengan form pencarian data bagi pasien lama, jika data ditemukan la terdaftar atau belum terdaftar serta membantu pelayanan efektif dan efisien.

2. Membuat sebuah sistem pencatatan data pasien, pemeriksaan pasien dan data obat membuat pihak Puskemas dengan mudah untuk mengarsipkan data pemeriksaan yang bersifat rahasia.

3. Membuat pengelolahan laporan puskemas seperti data pasien, data pemeriksaan dan data obat yang menggunakan sistem agar resiko untuk terjadinya kehilangan data tersebut di minimalisasi.

\section{DAFTAR PUSTAKA}

[1] Konli Steven, 2014. Pelayanan Kesehatan Masyarakat Di Puskemas Desa Gunawan Kecamatan Sesayap Kabupaten Tana Tidung.Samarinda:Universitas Mulawarman.

[2] Indra Beny Murphy \& Udjulawa Daniel, 2012. Fasilitas Sistem Informasi Akademik Berbasis WEB untuk SMA Negeri Oleh PT. XL AXIATA.Tbk Palembang. Palembang:STMIK GI MDP.

[3] Sembiring Hermansyah \& Nurhayati, 2012.Sistem Informasi Jumlah Angakatan Kerja Menggunakan Visual Basic pada Badan Pusat Statistik (BPS) Kabupaten Langkat. Binjai:STMIK Kaputama.
[4] Iskandar, 2016. Pelayanan Kesehatan Dalam Meningkatkan Kepuasan Masyarakat Di Rumah Sakit Panglima Sebaya Kabupaten Paser. Kalimantan Timur:Universitas Mulawarman

[5] Christian Hans, 2016. Penerapan Teknologi Responsive Web Designmenggunakan Library Bootstrap Untuk Pembuatan AplikasiE-journal pada Yayasan Bina Darma Salatiga. Jakarta:Universitas Kristen Satya Wacana.

[6] Halimah fitriah, dkk, 2017. Analisis Sequential SearchingAplikasi Kesehatan Balita Dan Ibu HamilSerta Pencarian Puskesmas Berbasis Android.Bandung: Universitas Telkom

[7] Yovi, dkk, 2015. Aplikasi Keamanan Lembar Hasil Studi Menggunakan AlgoritmaMessage Digest 5. Jurnal Psoudeode Unib 